\title{
ASSESSMENT OF THE WIND BEHAVIOR IN THE NORTHERN COAST OF SANTA CATARINA
}

\author{
ELIANE CRISTINA TRUCCOLO
}

\author{
Universidade Federal do Ceará, Instituto de Ciências do Mar, Laboratório de Oceanografia Física (UFC, \\ Labomar), Fortaleza, CE, Brasil \\ nane.truccolo@gmail.com
}

Received April 2010 - Acepted January 2011

\begin{abstract}
The spatial and temporal coherence of wind characteristics of coastal areas of Navegantes and Praia Grande, SC, $100 \mathrm{~km}$ apart each other, were assessed. Despite the relatively short distance, the oceanographic and geomorphological characteristics are different and can change the local and synoptic wind behavior, which are important for the understanding of the factors controlling the hydrodynamics and water quality of coastal environments. The comparison was performed through statistical analysis in the time and frequency domain, over a data set comprising hourly records from July to December, 1996. Both stations presented similarities regarding the north-south wind component. Therefore, quite different behavior is noticed for the east-west wind component, such as the breeze effect. The north-south wind pattern in Praia Grande is similar to the general wind regime for the Brazilian south-southwest areas, with dominance of northerly winds, and with southerly winds during the passage of cold-front systems, with small account of land-sea breeze. On the other hand, the breeze is the main factor contributing for the wind kinetics for the Navegantes area. We suggest that this differentiation is partially due to the combination of the mountain-valley circulation system of Vale do Itajaí with the breeze system, indicating a strong role of the local geomorphology on the wind regime. Additionally, it is may be possible that the sea surface temperature can also contribute, since there is a general trend of smaller temperatures southwards, though increasing the thermal gradient between the land and the sea.
\end{abstract}

Keywords: synoptic winds, breezes, northern coast of Santa Catarina.

RESUMO: ESTUDO DO COMPORTAMENTO DO VENTO NO LITORAL CENTRO-NORTE DE SANTA CATARINA.

Registros horários de velocidade e direção dos ventos em Navegantes e Praia Grande, SC, equidistante $100 \mathrm{~km}$, foram utilizados para avaliar a coerência espaço-temporal dos ventos entre as duas regiões costeiras. Apesar da pouca distância, as características oceanográficas e geomorfológicas destas regiões são distintas e podem alterar o comportamento dos ventos locais e sinóticos, de importância fundamental para a compreensão dos fatores que controlam a qualidade da água e hidrodinâmica em ambientes costeiros. O estudo foi conduzido através de análises estatísticas no domínio do tempo-freqüência durante Julho a Dezembro de 1996. Ambas as estações apresentaram similaridades no comportamento dos ventos norte-sul. No entanto, diferenças significativas foram observadas nos ventos de direção lesteoeste, como as brisas de terra e de mar. O comportamento do vento norte-sul na estação de Praia Grande é similar ao regime do vento na região sul-sudeste Brasileira, com predominância do quadrante norte, e sul durante a propagação de sistemas frontais. As brisas são uma componente menor da flutuação do vento. Em Navegantes, no entanto, essas componentes somaram a maior parte de toda energia cinética do vento. É sugerido que este fato se deve, em parte, à combinação com o sistema circulatório de ventos vale-montanha do Vale do Itajaí, indicando que o comportamento do vento nesta região pode ser alterado pela geomorfologia. Além disso, pode ocorrer influência da temperatura da superfície do mar menor nesta região, o que proporcionaria uma maior diferenciação térmica entre o continente e o oceano.

Palavras-chaves: ventos sinóticos, brisas, costa norte de Santa Catarina. 


\section{INTRODUCTION}

The coastal region of Santa Catarina has an extension of approximately $500 \mathrm{~km}$ and has a rich diversity of geomorphologic features: promontories, islands, peninsulas, coastal plains, estuaries, lagoons, inlets, bays, and sheltered or exposed beaches. The richness of features, and the shoreline orientation represent a complicating factor in the study of coastal oceanographic processes, such as oscillations in the estuarine and sea level, and currents at the inner continental shelf in relation to the movements induced by winds. Thus, it is important to evaluate the spatial-temporal variability of the prevailing atmospheric conditions and behavior of the winds, local and synoptic, to understand the factors that control the hydrodynamics and water quality in coastal regions.

Low atmospheric pressure systems in subtropics latitudes, such as extra tropical cyclones, introduce a significant variability in ocean movements on the time scales from days to weeks. These meteorological systems are nominated synoptic or sub-synoptic and influence directly the sea level, and consequently, the estuarine water level, causing oscillations as meteorological tides, storm surges, and can lead to coastal flooding through the action of north-south winds, longitudinal to the coast (Elliot, 1982; Geyer, 1997; Wong and Moses-Hall, 1998; Scully et al., 2005; Truccolo et al., 2006). Considering the general shoreline orientation of the south-southeast Brazilian coast, nearly southwest-northeast, sea-level rise is directly related to the action of the longitudinal winds to the coast, from south, and which result in displacement of water, transversal transport towards the coast and coastal subsidence. The opposite effect occurs with winds from the north, causing the lowering of the sea level and coastal upwelling. Both processes are explained by the Ekman mechanism (Castro and Lee, 1995). The water displacement takes place over large oceanic areas due to the broadness of the atmospheric forcing. The time scale of marine movements is from several days to weeks, known as low frequency, being function of the winds duration action.

In the last decades has been documented that for local scales, sea and land breezes, transversal to the coastline and typically of daily timescale (high frequency), have importance in local coastal oceanographic processes (Prandle, 1991; Militello and Kraus, 2001). In coastal environments, such as the inner continental shelf and semi-enclosed systems, such as estuaries, lagoons and bays, the breezes may be responsible for water movements that occur in daily periods. In the case of parallel to estuary orientation, they can induce setup and setdown due to a greater fetch for the wind action. These movements can have similar frequency to the main diurnal astronomical tidal constituents $\left(\mathrm{K}_{1}, \mathrm{O}_{1}, \mathrm{~S}_{1}\right)$, which can be combined with the local astronomical tide changing its forecast in the estuarine system
(Möller Jr. et al. 1996). Furthermore, the orientation of the estuary with respect to the coastline can determine whether the breezes and north-south effects on the estuarine hydrodynamics will be added or not. In estuaries with transverse orientation to the coast there will be the contribution of the breezes, acting on the estuarine surface, and the contribution of the north-south winds that changes the water level and currents in the adjacent shelf, occurring the opposition or combination of effects on estuarine hydrodynamics.

The objective of this study is to evaluate the temporalspatial coherence of the winds between two coastal regions distant 100 km, Navegantes and Praia Grande (SC), by statistical analysis of hourly time series of the wind in the time-frequency domain during the period from July to December 1996. Despite the relative short distance, the oceanographic and geomorphological characteristics of these regions are distinct and may change the synoptic and local winds behavior, which are important for the understanding of the factors controlling the hydrodynamics and water quality of coastal environments. The identification of similar weather conditions between these meteorological stations will allow that studies of hydrodynamics and sea level fluctuations of the nearby estuaries, weather-induced forcing identical, can be examined using data from meteorological stations more distant from the area of interest in the absence of a closer one. Additionally, this study may contribute to improve local weather forecast for the locations analyzed.

\section{STUDY AREA}

\subsection{Physical settings}

The study area covers two sites at the north-central coast of Santa Catarina. The Navegantes station (\#Nav, latitude $26^{\circ} 52^{\prime} \mathrm{S}$ and longitude $48^{\circ} 38^{\prime} \mathrm{W}$ ) is located to the south, and the station of Praia Grande (\#PGr, latitude $26^{\circ} 13$ 'S and longitude $48^{\circ} 29^{\prime} \mathrm{W}$ ) to the north (Figure 1), both are at sea level allowing the effect of sea-land breezes occurs in both regions. The \#Nav is located in the east of Vale do Itajaí, which begins near the town of Indaial (approximately $90 \mathrm{~km}$ inland, Figure 1) and ends between the cities of Itajaí and Navegantes, and \#PGr is near the mouth of Babitonga Bay. The shoreline orientation of these two regions differ a little from each other: \#Nav has a general north-south orientation and \#PGr presents orientation around $20^{\circ}$ in respect to the north. At regional scale the orientation of the state coast is north-south.

\subsection{Low level atmospheric circulation}

The wind regime in the study region is influenced by atmospheric processes of different temporal and spatial scales. 
Winds coming from the north quadrant, mainly from the northeast, predominate during the whole year. These synoptic winds are generated by semi-stationary high-pressure system (Figure 2a-2b), called the South Atlantic Anticyclone (SAA) or Atlantic Subtropical High that, according to Fedorova (2001), has an average location of about $30^{\circ} \mathrm{S}$. Humid and weak winds are characteristic for the entire region due to the large spatial scale of this system, which operates throughout the south and southeast coast and part of northeastern Brazil (Figure 2a-2b). However, changes in the weather take place in the south and southeast regions usually associated with the passage, formation or intensification of cold fronts, synoptic weather systems typical of middle latitudes and occurring in the Brazilian coast in all the seasons of the year (Kousky, 1979; Satyamurty et al., 1998). The cold fronts that pass through the South America coast can reach latitudes around $20^{\circ} \mathrm{S}$, where it begins the process of dissipation, known as frontolysis (Oliveira, 1986; Satyamurty e Mattos, 1989; Cavalcanti e Kousky 1996).

The frontal systems are generated from the meeting of cold air from the Polar Mobile Anticyclone (PMA) with the hot air mass from the SAA. The meeting between these two different air masses leads to a system of fronts. The frontal system can be severe and result in an extra tropical cyclone, being configured as the main process of meso-scale weather for the southsoutheast of Brazil (Rodrigues et al. 2004). According to Stech

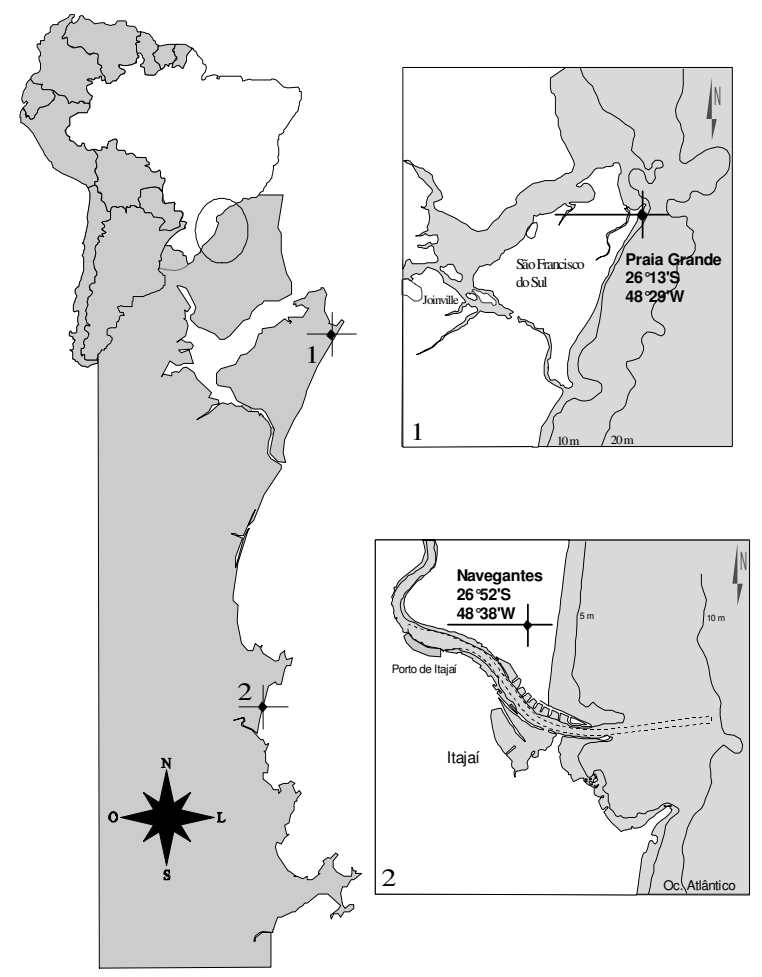

Figure 1 - Localization of the study area with indications of the sampling stations: (1) Praia Grande and (2) Navegantes. and Lorenzzetti (1992), during its propagation is observed the inversion of winds direction from north quadrant to the south quadrant in a counterclockwise rotation: from north-northeast to the northwest, southwest and south-southeast. After its passage PMA predominates which keep the wind from the south quadrant for periods of about 3 days, when it dissipates and the northeast winds return, typical of SAA.

The cold fronts climatology on the Santa Catarina coast, defined by Rodrigues et al. (2004) in a study based on 10 years of reanalysis data from NCEP-NCAR (National Center for Environmental Prediction - National Center for Atmospheric Research), shows the typical trajectory of the cold fronts from southwest to northeast, within a 3-days period on average. According to the study, the average monthly frequency is 3 to 4 cold fronts passing through SC in all months of the year, with a slightly greater number of these systems during the spring. However, one can identify a seasonal variation in the post-frontal wind field: in the winter, a strong southwest flow is observed two days after the frontal passage, in association with extra tropical cyclones, which intensify in the ocean at latitudes near the south coast of Brazil (Gan and Rao, 1991); in the summer, cyclones travel into higher latitudes and southeast winds are typical of a post-frontal condition in the Santa Catarina coast, associated with the performance of low pressure systems (cyclones and troughs) that take place at the southeastern coast of Brazil after the frontal passage in this region (Rodrigues et al., 2004).

Combined to the synoptic winds, local winds, land and sea breezes, occur in the study region due to the daily variation of the local atmospheric pressure, resulting of the differential heating and cooling that are established between the land and surrounding sea. The winds are observed on hot days and especially during the summer and spring, crossing the coast line and extending to about 3,000 m of altitude (Fedorova, 2001). In relation to winds at synoptic scale, the breezes have smaller spatial and temporal scale, working daily and locally. Another type of secondary circulation of a similar scale to the

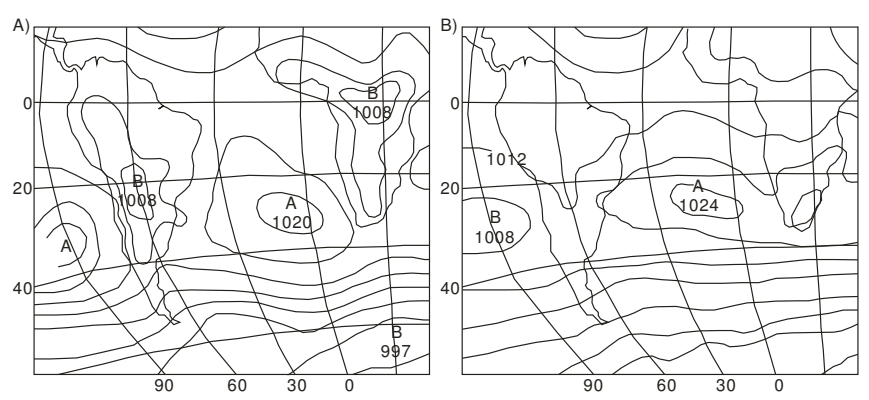

Figure 2 - Atmospheric pressure at mean sea level (a) for the January and (b) July months (modified from Hromov, 1964, apud Fedorova, 2001, p.152 and 153). 
breeze, and that can influence the wind regime in the study site is the mountain-valley circulation. The mountain-valley winds originate from the differential heating or cooling air over the valleys and mountain slopes, establishing a movement similar to the breeze (Figure 3). According to Fedorova (2001), when mountainous areas are situated close to the sea coasts, mountainvalley circulation combines with the land and sea breezes: during the day-time, the valley-to-mountain winds and sea breeze in the direction of the mainland and above the slopes of the mountains are reinforce.

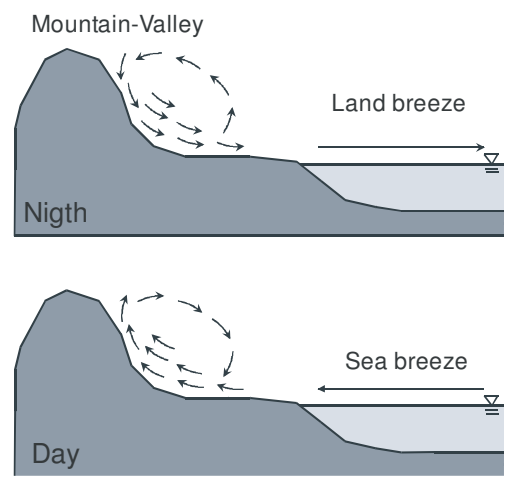

Figure 3 - The mountain-valley winds configuration (modified from Fedorova, 2001).

\section{MATERIAL AND METHODS}

The time series consisted of hourly records of wind speed and direction for the meteorological stations \#PGr and \#Nav during the period from July to December 1996, totalizing 6 months (Figure 4). For this study, there was a need of simultaneous data between the two stations, which reduced the length of hourly time series in about 150 days, covering the period of winter, spring and early summer. The \#PGr series consisted hourly data obtained with an automatic weather station (Campbell ${ }^{\mathrm{TM}}$ ) with the wind sensor installed to a height of 10 $m$ during the period of execution of the project "Environmental studies on coastal and ocean areas in the south of Brazil", UFSC/ Petrobrás/1995 Agreement. The \#Nav series were provided by Infraero of the Navegantes airport, with similar altitude of the sensors. The wind direction was subtracted from the value of $17.2^{\circ}$ resulting from the magnetic declination for the year of 1996. The data gaps in hourly time series did not exceed 6hs, being filled by interpolation.

The wind was decomposed into north-south and eastwest components according to the coastline orientation. This was done based on previous work done in $\mathrm{APGr}$, where Truccolo et al. (2006) identified that the north-south winds, with longitudinal orientation to the coast, maximize the response of the coastal sea level oscillations, inducing positive and negative anomalies to the ocean surface on long time scales of several days. In order to obtain the fluctuations of the wind at low frequency (Figure $4 d-4 e)$, the components were filtered with a quadratic low-pass filter Lanczos with a cutoff for oscillations with frequencies lower than $40 \mathrm{hs}$. The seasonal component was eliminated by subtracting the linear trend of each series. The high frequency component from each series was obtained with Fourier band pass filter (keeping energy between $1 \mathrm{~h}$ and $24 \mathrm{hs}$ ).

The winds characteristics in the two regions and spatialtemporal coherence between them were investigated using statistical analysis in the time and frequency domain, as analysis of variance and spectral analysis. Spectral analysis allowed characterizing in more details to the distribution of the variance in the frequency domain, then being used for this purpose in all observed time series. Overlap and sum method from Welch was used (WEI, 1994), which consists of to split the original record in blocks, estimating the spectrum for each block, and finally calculate the average of the results. The spectra were obtained with 12 degrees of freedom.

\section{RESULTS AND DISCUSSION}

\subsection{General characteristics of the time series}

The atmospheric pressure at mean sea level (APMSL) for both stations showed significant fluctuations with strong and quick decreases of values during the study period (Figure 4a). These oscillations are strongly related with the propagation of frontal systems across the region. To confirm this relationship, in Table 1 are presented the number of frontal systems and their days of actuation in southern Brazil, according to Climanálise Bulletin of the Center for Weather Forecasting and Climate Studies - CPTEC/INPE (Climanálise, 1996). The APMSL oscillations observed in both \#NAV and \#PGr have occurred approximately in the same days in which were recorded the passages of the fronts presented in Table 1.

The variability of the wind was representative of typical conditions of winter and spring only to the \#PGr (Figure 4b-4d), with predominant north-south winds. In the \#Nav (Figure 4c-4e) there was a dominance of the east-west direction of the wind, with quicker inversions. The Figure 5 presents the data of wind speed and direction for both stations through polar diagrams. In the \#PGr (Figure 5a) was observed 3 predominance in wind direction: (1) north-northeast winds, more expressive, with speeds from 2-5 m.s $\mathrm{s}^{-1}$, which correspond to the movement of the SAA; (2) from east to west, with speeds of about $2 \mathrm{~m} . \mathrm{s}^{-1}$, corresponding to the local driving forces such as land and sea breezes; and (3) the southeast direction, reaching the highest values of velocities, around 6 to $8 \mathrm{~m} \cdot \mathrm{s}^{-1}$, corresponding in 


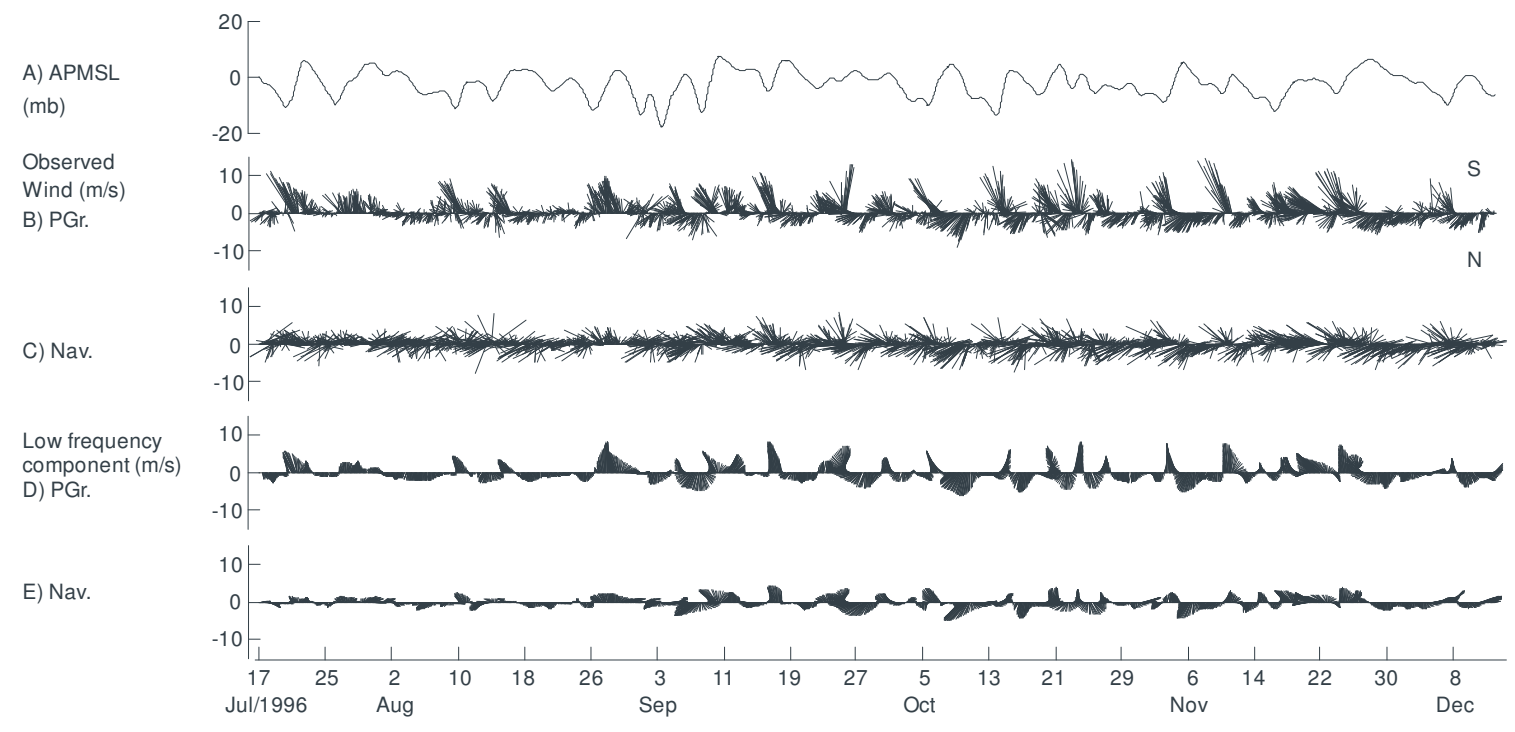

Figure 4 - Hourly time series of: (a) atmospheric pressure anomaly at mean sea level (APMSL), observed wind (b) in the \#PGr and (c) in the \#Nav, low frequency components of the wind (d) at the \#PGr and (e) at the \#Nav. The letters S and N (north and south, respectively) indicate the direction of the winds in meteorological notation.

part to overlapping effects of the synoptic and local forcing. The intensity of the winds in the \#Nav in comparison with the \#PGr was lower. The most frequent winds were east-west, with speeds of around $2 \mathrm{~m} . \mathrm{s}^{-1}$, and suggesting that breezes were more significant. Winds from the north-northeast and southeast, despite less frequently, had the highest intensity, of about $8 \mathrm{~m} \cdot \mathrm{s}^{-1}$.

\subsection{Time domain analysis}

Through the decomposition of the time series variance of APMSL and of the wind components in the \#PGr and \#Nav, it was possible to know the relative dominance of the atmospheric processes occurring in three frequency ranges: high, low and trend (Table 2). The phenomena that have occurred on time scales of several days, as synoptic weather systems, dominated the total variance of APMSL in the two stations. The north-south component of wind also showed a greater variance in these scales. However, the east-west component of wind showed significant differences between \#PGr and \#Nav. While at the
\#PGr there was a small predominance in the range of a longperiod $(47 \%)$, at the \#Nav approximately ${ }^{2} / 3$ of the variance of the wind (around 68\%) were from daily contribution, such as breezes and mountain-valley winds, and only $27 \%$ represented processes that have occurred on time scales of days.

\subsection{Frequency domain analysis}

The APMSL spectrums for the both stations were nearly identical (Figure 6c), with the major energy in the low frequency band, where there are the major changes of weather systems at the synoptic scale. The energy spectrums of the wind components are shown in Figure 6a-6b. For each component, the spectrums were similar between the two stations. The general trend observed showed increases at low frequencies, particularly in 7 days to north-south component, and at high frequencies, around $24 \mathrm{hs}$, to east-west component. However, the energy level of the north-south component was consistently higher at the \#PGr, especially on time scales of 6-8 days, exceeding by

Table 1. Number of frontal systems (No. FS) and days that have actuated in southern Brazil during the months of study (modified from Climanálise, 1996).

\begin{tabular}{c|c|c|c|c|c|c|c|c}
\hline 1996 & No. FS & \multicolumn{9}{|c|}{ Days } \\
\hline July & 6 & 3 & 6 & 8 & 14 & 18 & 25 & \\
\hline August & 6 & 5 & $7-8$ & 10 & 14 & 21 & 26 & \\
\hline September & 6 & 1 & 3 & 8 & 16 & 19 & 22 & \\
\hline October & 6 & 6 & $9-10$ & 12 & 21 & 27 & 28 & \\
\hline November & 7 & 1 & 3 & 8 & 10 & 13 & 17 & $24-25$ \\
\hline December & 7 & 1 & 5 & 7 & 13 & 17 & 20 & $27-30$ \\
\hline
\end{tabular}



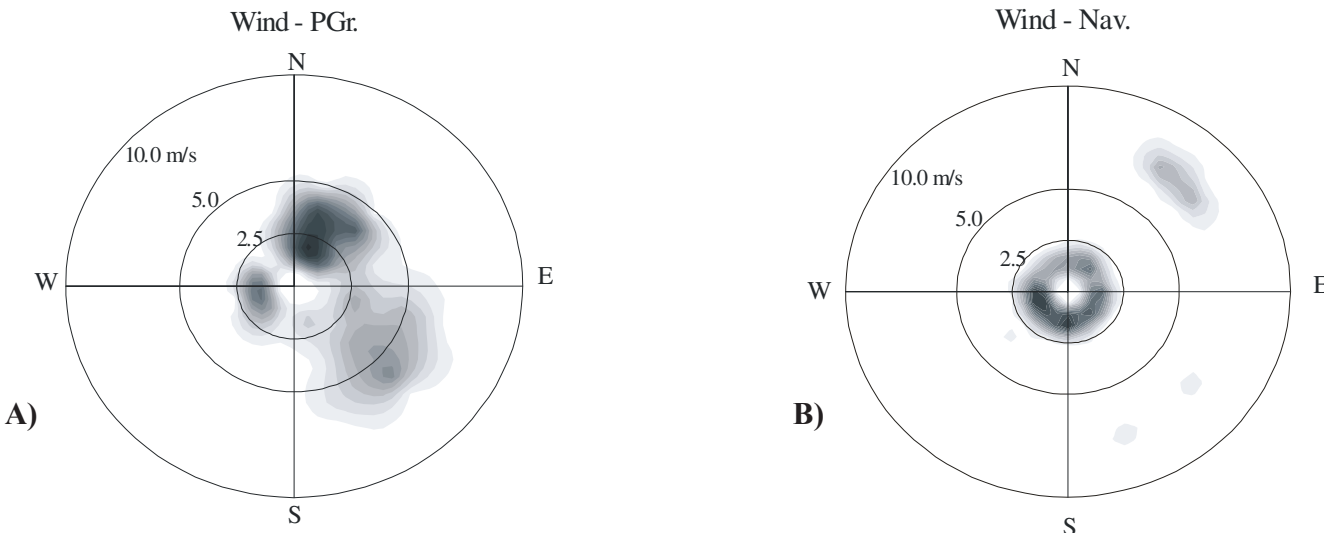

Figure 5 - Diagrams of polar distribution of winds: (a) \#PGr (modified from Truccolo, 1998) and (b) \#Nav.

a factor of three the same component at the \#Nav (Figure 6a), suggesting that much of the kinetic energy is associated with the propagation of synoptic weather systems. The east-west component was only a minor component of the wind fluctuation at the \#PGr during the study (Figure 6b).

The energy level of the east-west component of wind at the \#Nav was consistently higher than the same component at the \#PGr (Figure 6b), exceeding by factor of three for the same component. Additionally, the east-west winds presented a slightly higher level than the north-south at the \#PGr, indicating that, even during the winter, the component contributed to the majority of the kinetic energy of the wind, contained in daily periods and associated with local winds, having as much or more importance as the winds associated with synoptic scale systems. When we consider the spectrum of coherence between the north-south components of the stations, it becomes clear that these are highly coherent for periods longer than 5 days, periods with greater amounts of energy. The east-west winds are highly consistent for periods around $24 \mathrm{hs}$. This behavior is due to action of local and synoptic forcing in both regions studied.

However, despite these results demonstrate the sum of energy distributed on time scales are similar for both stations (7 days, north-south winds, and $24 \mathrm{hs,} \mathrm{east-west} \mathrm{wind),} \mathrm{it}$ was identified large differences in energy levels between the respective components. In fact, the winds at the \#PGr followed the pattern observed on the Brazilian south-southeast coast, with winds mainly from the southern quadrant contributing with greater energy, being stronger due to the propagation of synoptic systems, typically more intense during the winter. However, this pattern was not observed at the \#Nav, been the east-west winds more energetic, overlapping even the northsouth component.

\subsection{Mountain-valley wind system effects}

To better show the detailed behavior of winds at the \#Nav and \#PGr, the variability of the components was observed in separate frequency bands, high and low, for the period from July to August (Figure 7). At the \#Nav, the variations of winds at high frequency, which represent the sea and land breezes, are clear throughout the entire record, being more significant than the analogues at the \#PGr. The north-south wind component, representative of low frequency oscillations, were significantly weaker compared to the one at the \#PGr, and have coincided with periods of higher intensity of the east-west component. Despite the winds coming from both north and south quadrants have their origin associated with the synoptic weather systems, local winds at daily time scale seem reduce them at the \#Nav in at least five events in the periods of July 20 to August 01 and August 10 to

Table 2 - Variance (in \%) of the components of high, low frequency and trend, for atmospheric pressure at mean sea level (APMSL), north-south (NS) and east-west (EW) wind components for Praia Grande (\#PGr) and Navegantes (\#Nav).

\begin{tabular}{c|c|c|c|c|c|c}
\hline Components & \multicolumn{3}{|c|}{ \#PGr } & \multicolumn{3}{c}{ \#Nav } \\
\hline & MSLAP & N-S & E-W & MSLAP & N-S & E-W \\
\hline High frequency & 3.5 & 41.2 & $\mathbf{4 4 . 3}$ & 3.1 & 45.4 & $\mathbf{6 8 . 2}$ \\
\hline Low frequency & 68.0 & $\mathbf{5 3 . 9}$ & $\mathbf{4 6 . 6}$ & 63.1 & $\mathbf{5 1 . 8}$ & 27.5 \\
\hline Trend & 28.5 & 4.9 & 9.1 & 33.8 & 2.8 & 4.3 \\
\hline
\end{tabular}



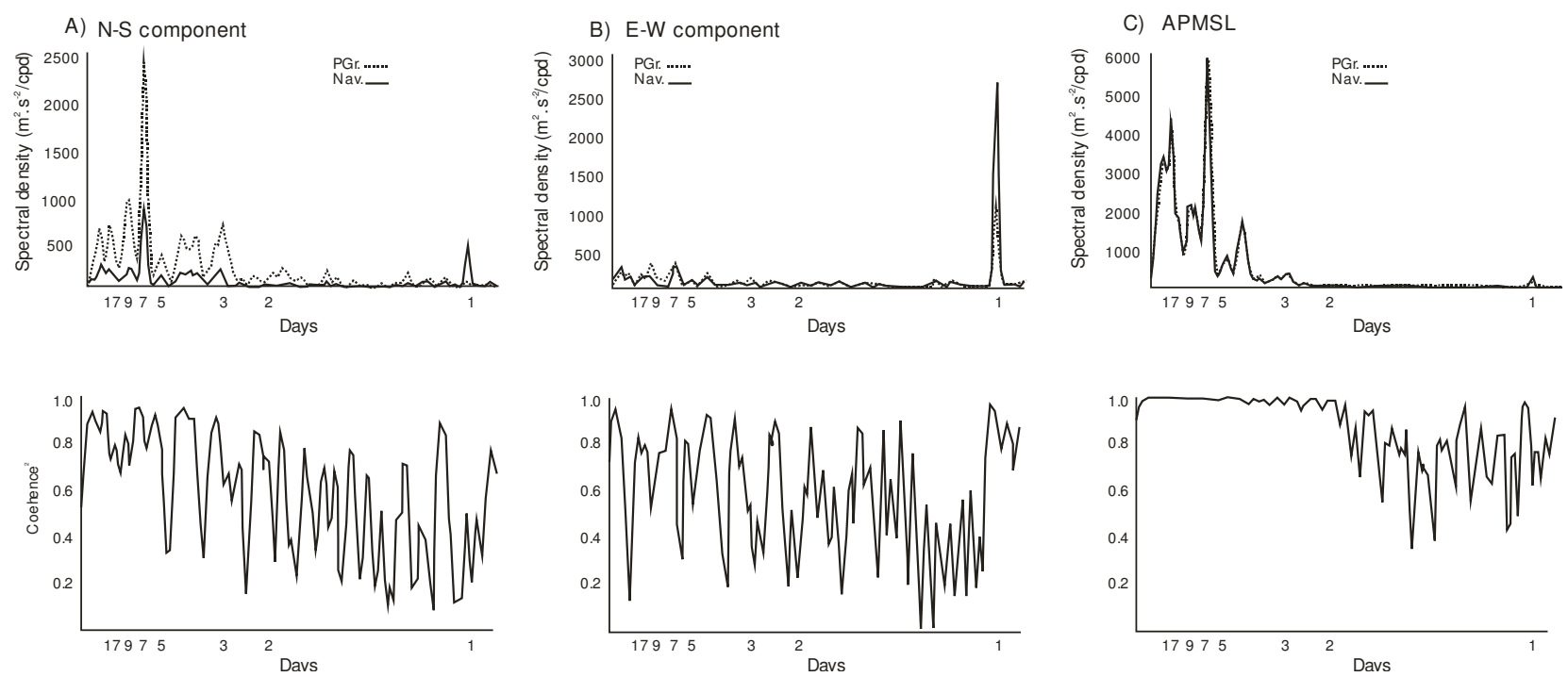

Figure 6 - Spectral density and coherence: (a) north-south component, (b) east-west component and (c) APMSL.

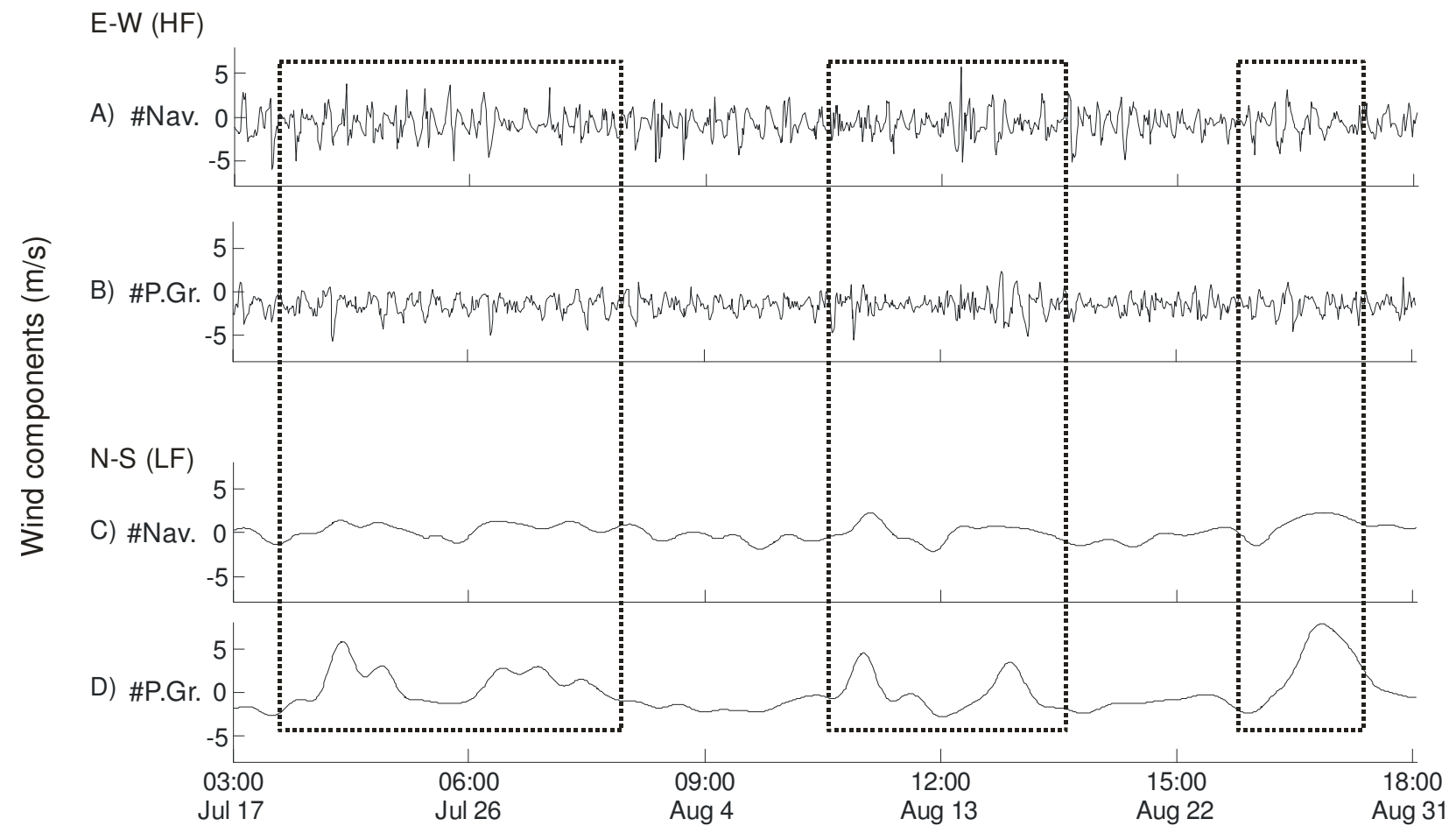

Figure 7 - East-west (ab) and north-south (cd) wind components at \#Nav and \#PGr. Positive values of the component indicate winds originating from south and west. Components of high and low frequencies are called HF and LF, respectively.

18 , and at the end of the period (Figure 7, indicated by the dashed line). This pattern may be possibly associated with the proximity of the Vale do Itajaí, and the effect of this to channelize the wind in these directions. In addition, there may be a land-sea thermal differentiation bigger at the \#Nav due to lower sea surface temperatures (SST) in this region. According to Carvalho et al. (1998), the SST decreases from north to south in the north coast of $\mathrm{SC}$, and as it is expected that the continent temperature does not decrease with the same intensity, there are arguments to expect better breeze conditions in Navegantes. 
The Vale do Itajaí presents a similar configuration to a convergent valley towards the mainland, as can be seen in the hypsometric map of the region (Figure 8). Then air can be channelized along the valley resulting in a combination of winds blowing over the valley and the slopes of the mountains combined to the sea and land breezes. According to Fedorova (2001), mountain-valley winds occur due to differential heating between the mountain slopes and adjacent valleys during the day and night (Figure 3). This originated horizontal temperature gradients, resulting in a circulation cell with rising movements along the mountain slopes and descending movements on the valleys during the day. At night, the configuration of the outflow is contrary to the daytime with rising movement and clouds being developed on the valleys. Due to the proximity of mountainous regions to the Navegantes, this valley-mountain circulation system seems to combine with the already existent sea and land breezes. It is suggested that during the day mountain-valley winds and sea breezes are strengthened, in the direction of the continent and up the mountain slopes. As with the sea breezes, mountain and valley winds are, in general, superimposed on the common winds regime (Fedorova, 2001).

\section{CONCLUSIONS}

Despite the short time series, it was possible to compare the weather conditions in the stations of Navegantes and Praia
Grande located in the northern coast of Santa Catarina. The temporal-spatial coherence analysis of the winds indicated that both stations presented, in general, similarities in the winds behavior of frequency of days, like those who blow in the north-south direction originated by synoptic weather systems. However, significant differences between the two regions were observed in the local winds that act in daily periods, such as land and sea breezes.

The Praia Grande station has the wind regime similar to the Brazilian south-southeast regional wind regime, with a predominance of winds from the north and south during the propagation of frontal systems. The east-west winds are a minor component of the wind fluctuation and are associated with the local driving forces, such as sea and land breeze.

At Navegantes, even when the winds from the south became more intense, sea and land breezes accounted with most of all the kinetic energy of the wind. It is suggested that this is due to the combination with the mountain-valley circulatory system of the Vale do Itajaí, indicating that this region has geomorphologic characteristics which alter the pattern of action of the winds. Additionally, there may be influence of lower SST in this region, which would provide a greater thermal difference between the continent and ocean.

The results presented in this study reinforce the idea that, in regions near the valleys, the combination of land-sea breeze and mountain-valley winds may be superimposed on

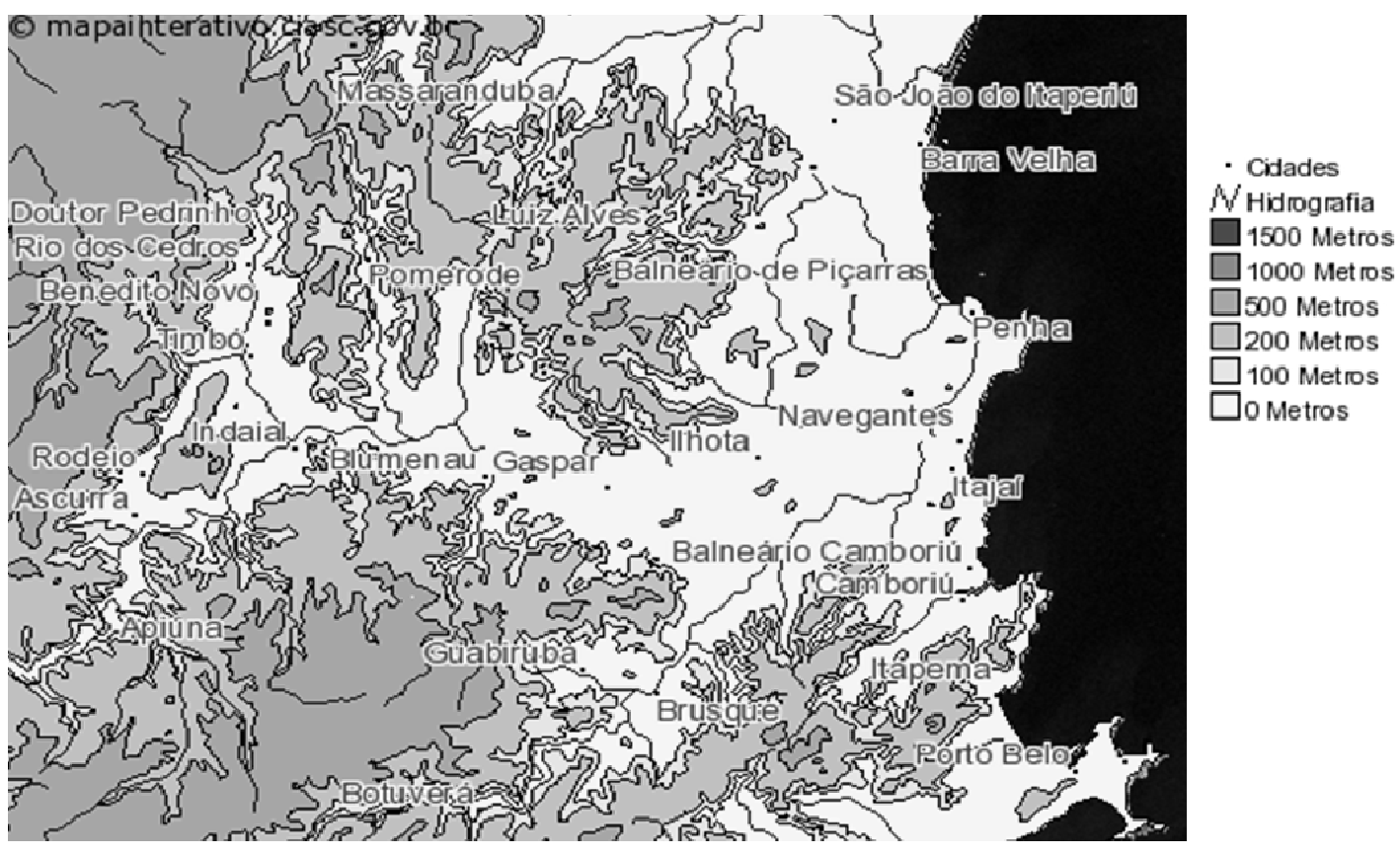

Figure 8 - Hypsometric map of the Vale do Itajaí. (Source: CIASC) 
the winds regime of synoptic nature with effects on the coastal surface circulation, playing a role that should be taken into account in coastal hydrodynamics studies and of weather forecast in the region. In addition, the markedly difference in the importance of daily phenomena between the two stations, and the lower intensity of north-south component at Navegantes when compared to Praia Grande, indicated the need for maintenance or increase of spatial density of meteorological stations in this region. Finally, for a better understanding of the causes of differentiation of synoptic and local winds in the region, it is suggested the development of studies that consider a longer period of data and considering also the analysis of SST.

\section{ACKNOWLEDGEMENTS}

I would like to thank to Infraero (Empresa Brasileira de Infra-Estrutura Aeroportuária) of the Navegantes airport for the data series at Navegantes station, Petrobrás (Petróleo Brasileiro S/A) and Universidade Federal de Santa Catarina for the financial support through the project "Environmental studies on coastal and ocean areas in the south of Brazil". I am grateful to the anonymous reviewers for its valuable contribution and, in special, to Carlos A. F. Schettini, for improving the manuscript.

\section{REFERÊNCIAS BIBLIOGRÁFICAS}

CARVALHO, J. L. B.; SCHETTINI, C. A. F.; RIBAS, T. M. Estrutura termohalina do litoral centro-norte catarinense. Notas Técnicas da Facimar, Itajaí, SC, v. 2, p. 181-197, 1998.

CASTRO Fo., B. M.; LEE, T. N. Wind-forced sea level variability on the southeast Brazilian shelf. Journal of Geophyscal Research, v. C8, n. 100, p. 16.045-16.056, 1995.

CAVALCANTI, I. F.; KOUSKY, V. E. Configuração de anomalias associadas à propagação de sistemas sinóticos sobre a América do Sul. Congresso Brasileiro de Meteorologia, IX, Anais... Campos do Jordão, SP, p. 1331-1332, 1996.

CIASC - Centro de Informática e Automação do Estado de Santa Catarina - http://www.mapainterativo.ciasc.gov.br/. Acesso em: 20 de ago. 2009.

CLIMANÁLISE, 1996. Boletim de no. 11. Volumes 07 a 12. Disponível em http://climanalise.cptec.inpe.br/ rclimanl/ boletim/. Acesso em: 30 de fev. 2009.

ELLIOT, A. J. Wind-driven flow in a shallow estuary. Oceanologica Acta, v. 5, p. 7-10, 1982.

FEDOROVA, N. Meteorologia Sinótica. Universidade Federal de Pelotas, Pelotas, Rio Grande do Sul: Ed. Universitária, 2001. 242 p.
GAN, M. A.; RAO, V. B. Surface cyclogenesis over South America. Monthly Weather Review, v. 119, p. 1293-1302, 1991.

GEYER, W. R. Influence of wind on dynamics and flushing of shallow estuaries. Estuarine, Coastal and Shelf Science, v. 44, p.713-722, 1997.

KOUSKY, V. E. Frontal influences on Northeast Brazil. Monthly Weather Review, v. 107, p. 1140-1153, 1979.

MILITELLO, A.; KRAUS, N. C. Generation of harmonics by sea breeze in nontidal water bodies. Journal of Physical Oceanography, v. 31, p. 1639-1647, 2001.

MÖLLER Jr., O. O.; LORENZZETTI, J. A.; STECH, J. L.; MATA, M. M. The Patos Lagoon summertime circulation and dynamics. Continental Shelf Research, v. 3, n. 16, p. 335-351, 1996.

OLIVEIRA, A. S. Interações entre sistemas frontais na América do Sul e convecção na Amazônia. INPE - 4008-TDL/239, 1986.

PRANDLE, D. Tides in estuaries and in embayments (Review). In: PARKER, B.B. (Org.). Tidal Hydrodynamics. New York: John Wiley and Sons. 1991. p. 125-152.

RODRIGUES, M. L. G.; FRANCO, D.; SUGAHARA, S. Climatologia de frentes frias no litoral de Santa Catarina. Revista Brasileira de Geofísica, v. 22, n. 2, p. 135-151, 2004.

SATYAMURTY, P.; MATTOS, L. F.; NOBRE, C. A.; SILVA DIAS, P. L. Tropics - South America. In: KAULY, D. J. e VINCENT, D. G. Meteorology of the Southern Hemisphere. American Meteorological Society, Boston, 119-139, 1998.

SATYAMURTY, P.; MATTOS, L. F. Climatological lower tropospheric frontogenesis in the midlatitudes due to horizontal deformation and divergence. Monthly Weather Review, v. 117, p. 1355-1364, 1989.

SCULLY, M. E.; FRIEDRICHS, C. T.; BRUBAKER, J. M. Control of estuarine stratification and mixing by windinduced straining of the estuarine density field. Estuaries, n. 28, p. 321-326, 2005.

STECH, J. L.; LORENZZETTI, J. A. The response of the South Brazil Bight to the passage of wintertime cold fronts. Journal of Geophysical Research, v. C6, n. 97, p. 9.5079.520, 1992.

TRUCCOLO, E. C. Maré meteorológica e forçantes atmosféricas locais em São Francisco do Sul - SC. 1998. 100 f. Dissertação (Mestrado em Engenharia Ambiental) Universidade Federal de Santa Catarina. Florianópolis. 1998.

TRUCCOLO, E. C.; FRANCO, D.; SCHETTINI, C. A. F. The low frequency sea level oscillations in the northern coast of Santa Catarina, Brazil. Journal of Coastal Research, v. SI39, p.547-552, 2006. 
WEI, W. W. S. Time Series Analysis - Univariate and Multivariate Methods. New York: Addison-Wesley Publishing Company, 1994. 478 p.
WONG, K.- C.; MOSES-HALL, J. E. On the relative importance of the remote and local wind effects on the subtidal variability in a coastal plain estuary. Journal of Geophysical Research, v. 3, p. 18393-18404, 1998. 